\title{
Winged Transportation
}

\section{A Survey of Commercial Air Services Both Here and Abroad}

By Ladislas d'Orcy

THE saying, "Distance lends enchantment," is particularly true in respect to commercial aviation. Anyone reading foreign aeronautical magazines can easily gather the impression that Europe is sim ply seething with air transport activities that any reputable firm desirous of establishing an airway is promptly subsidized by its government; that Europe is covered with commercial air lines, and so forth.

As a consequence few people realize how far American achievements have outstripped foreign accomplishments in the matter of air transport. With a view to correcting many fanciful views on this subject, an attempt is made here to present in a readable form all the essential information regarding air-transport activities in the United. States and abroad. This includes the air routes in operation and projected, the names of the companies operating them, the type of aircraft used and the length of every rout

A cursory examination of this information will reveal to the reader that the longest regularly operated airway in the world is the United States air mail route from Washington to San Francisco (2,484 miles), while abroad there are but two airways of over 1,000 miles' length, neither of which exceeds 1,200 miles.

One of these connects Toulouse, France, with Casa blanca, Morocco, and has tri-weekly service, while the other operates in the Belgian Congo on the schedule of three trips per month. Both lines traverse territory which is ideal for flying: fogs are practically unknown in those regions, elevations are moderate, if any, atmospheric conditions are, except for certain well defined seasons, remarkably even, and landing places are frequent.

On the American transcontinental air route flying conditions are far from being so favorable. Fogs are very frequent on certain sections, violent winds prevai over the Rocky Mountains and over the Alleghenies, extreme colds are encountered in the winter, and nat ural landing places are often few and far between. It follows that the ground organization required for making of our transcontinental air line a success involved problems far more difficult to solve than could be met on the two African routes. Furthermore, while the United States air mail operates daily, except on Sundays, the two foreign lines are under contract to run only tri-weekly and five monthly services, respectively. Taking into consideration all of these factors, it can be said without overstatthat the United States is by far in the lead in air transport activities. It may be objected that our transcontinental airway does not transport passengers and goods, while practically all the foreign air transport services do so. But this argument has little weight against the fundamental fact that there exists between the Atlantic and the Pacific an air route equipped with air ports, supply depots and emergency landing fields which is readily available for public air transport That its use has so far been confined to the carriage of mails does not invalidate the fact: it merely illustrates certain local conditions.

This naturally brings up the question of the air transport subsidies. So far only France has adopted this policy, although it appears to be the consensus of opinion abroad that public air transport services will not be able to make profit or even cover expenses for the next few years without some sort of government assistance. It may be asked why the government should be expected to step in here and act as a godfather to the air lines instead of letting the latter flourish or perish on their own merit.

The answer to this query is that, as the next war will undoubtedly be a real first class air war, startin with bombing raids on barracks, dock yards, concentration points, railroad junctions, etc., reasons of nationa defense make it imperative for the United States to have a powerful air force. But as financial considerations make it impossible to maintain in times of peace the air force we will need in a war of any importance, purely commercial-and therefore profitable-machines. The British government, on the other hand, provides only indirect assistance to air transport firms in that it assumes responsibility for the organization of air ports, the wireless and weather services, and research and experimental work. Clear thinking Englishme begin to realize, however, that this assistance is not sufficient to enable their air transport enterprises to "carry on" during the period in which converted war material is being used up. In this respect it is significant that the British Advisory Committee for Civil Aviation in its recently issued report went on record as favoring a scheme of air transport subsidy that would grant financial assistance in proportion to service rendered.

Other countries, like Poland and Czecho-Slovakia, grant subsidies in the form of a lump sum per mail flight on approved routes.

In this country Government assistance entered the In this country Government assistance entered the tracted with several air transport companies for the carrying of mails on approved routes and schedules. This system, which essentially consists in paying a given sum for a given service, is undoubtedly sound in principle. Still, it is open to criticism insofar as it excludes competition and so does not encourage performance beyond that strictly necessary to fulfil the terms of the contract. Nevertheless, such as it is, our mail contract system is at least as good as, if not better than, the foreign system of subsidy already mentioned.

Below there is given a tabulation of the world's air transport services as far as information is available. The services sted include those actually in operation as well as listed include those actually in operation as well as respective governments. It should be noted that all respective governments. It should be noted that an operated and that almost all carry passengers, although some do not carry mails. All the French air lines listed are subsidized, the services to Prague and Warsaw being also subsidized by the Czecho-Slovak and Polish governments, while the Malaga to Casablanca line also draws a subsidy from the Spanish government. The German air transport services, which are subsidized in some form by the German government, operate on more or less irregular schedules, owing chiefly
to the scarcity of gasoline. It is possible that service on some of the routes listed has been suspended until next spring.

No recent information is at hand regarding the Colombian and Far Eastern air transport companies and the information is merely given for the sake of and the inform

\section{THE WORLD'S AIR TRANSPORT SERVICES} United States

(A) Government Owned and Operated Service

(The United States is the only country in the world to have a government-owned and operated air transport service.)

U. S. Air Mail Service, Post Office Department, Washington, $\mathrm{D}$. $\mathrm{C}$.

Routes: (1) Washington-New York (218 miles). Daily, except Sundays.

(2) New York-Cleveland-Chicago-Omaha-Cheyenne-Salt Lake-Reno-San Francisco $(2,266$ miles $)$. Daily, except Sundays. (3) St. Paul-Chica'go-St. Louis (610 miles). Daily, except Sundays.

Fleet: Forty DH-4M (400 hp. Liberty). Fleet: Forty $\mathrm{D}$
Mail load, $400 \mathrm{lb}$.

Twenty Twin DH (two 200 hp. Liberty). Mail load, $600 \mathrm{lb}$

Seventeen Curtiss R-4-LM (400 hp. Liberty). Mail load, $400 \mathrm{lb}$.

Seven Curtiss JN-4H (150 hp. Wright). Mail load, $200 \mathrm{lb}$

Seven Curtiss-Standard J-1 (150 hp.

Wright). Mail load, 200 lb.

Five Junkers, JL.6 (240 hp. B.M.W.). Mail load, 1,000 lb.

Three G. L. Martin (two 400 hp. Liberty). Mail load, 1,500 lb.

Two Curtiss HA. (400 hp. Liberty). Mail load, $800 \mathrm{lb}$

One L.W.F. (240 hp. Isotta-Fraschini). Mail load, $600 \mathrm{lb}$.

Delivery of twelve DH-4M and forty-nine L.W.F. mail airplanes is pending.

(B) Privately Owned and Operated Services Aeromarine West Indies Airvays, Inc., New York.

Route: Key West-Havana (106 miles). Daily, except Sundays.

Fleet: Six F-5-L (two $350 \mathrm{hp}$. Liberty) cabin flying boats. Mail load, 500 lb. Passenger capacity, 11. Carry U. S. mails.

Hubbard Air Transport Company, Seattle, Wash.

Route: Seattle-Victoria, B. C. (84 miles). Ten trips per month.

Fleet: Boeing seaplanes and flying boats. Carry U. S. mails.

Aero Limited. New York. 
Route: Miami-Bimini-Nassau, B.W.I. (200 miles). Irregular

Fleet: F-5-L (two $350 \mathrm{hp.} \mathrm{Liberty)} \mathrm{and} \mathrm{HS-2L} \mathrm{(350}$ hp. Liberty) flying boats. Passenger capacity, twelve and six, respectively.

America Trans-Oceanic Company. New York.

Route: Miami-Bimini-Nassau, B.W.I. (200 miles). Irregular.

Fleet: Curtiss H-16 (two 350 hp. Liberty), HS-2L (350 hp. Liberty), Curtiss Seagull (150 hp. Curtiss) and Curtiss MF (90 hp. Curtiss) flying boats.

Lawson Airline Company. Chicago.

This company is under contract with the U. S. Post Office Department to carry mails on a daily schedule on the following routes:

(1) New York-Harrisburg-Pittsburgh-Fort WayneChicago ( 735 miles)

(2) Pittsburgh-Columbus-Cincinnati-Indianapolis-St Louis (600 miles).

(3) New York-WashingtonRaleigh-Columbia-Atlanta (815 miles).

A fleet of three-engined cabin airplanes having a mail capacity of $1,500 \mathrm{lb}$. and accommodations for sixteen passengers is under construction. Service on route 1 is to start next spring.

Mercury Aviation Company. Hollywood, Cal.

This company, which for the last year has been operat ing irregular air transport services in southern Califor nia, proposes to. establish next spring a regular passen ger air line between Los Angeles and San Francisco (340 miles)

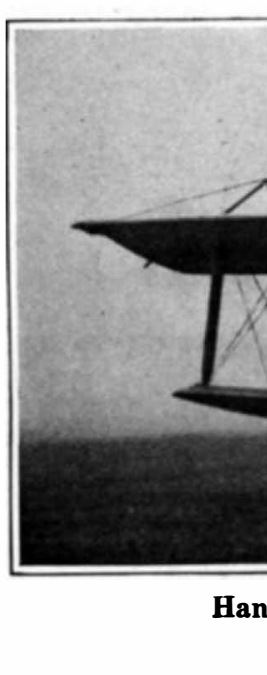

\section{France}

Compagnie Générale Transaérienne. Paris.

Route: Paris-London (223 miles). Tri-weekly.

Fleet: Nieuport cabin airplanes.

Compagnie des Messageries Aériennes. Paris.

Routes: (1) Paris-London (223 miles). Tri-weekly.

(2) Paris-Brussels (155 miles). Tri-weekly.

(3) Oran-Casablanca (450 miles). To open next spring.

Fleet: Bréguet $320 \mathrm{hp}$. and $450 \mathrm{hp}$., cabin airplanes. Compagnie des Grands Express Aériens. Paris.

Routes: (1) Paris-London (223 miles). Bi-weekly. (2) Paris-Brussels (155 miles). Trips to be made tri-weekly.

Fleet: Farman Goliath (two 260 hp. Salmson) airplanes.

Co m pag nie Franco-Roumaine de Navigation Aéri enne, Paris.

Routes: (1) Paris-Strasbourg-Prague-Warsaw $\quad(875$ miles). Tri-weekly.

(2) Paris-Strasbourg-Vienna-Belgrade-Bucharest - Constantinople $(1,600$ miles $)$. To open next spring.

Fleet: Potez S.E.A. (320 hp. Lorraine).

Société "Aéro-Transport." Societe
Paris.

Route: Paris-Geneva (280 miles). Five trips per month.

Fleet: Salmson (260 hp.) airplanes.

Compagnie Francaise des Courriers Aériens AtlantiqueMéditerranée. Toulouse. Routes: (1) Toulouse-Bordeaux (130 miles). Four weekly.

(2) Toulouse-Montpelier-Marseille-Nice (330 miles). Four-weekly

Fleet: Salmson (260 hp.) airplanes.

Lignes Aériennes Latécoère. Toulouse.

Routes: (1) Toulouse-Barcelona-Alicante-MalagaTangier-Casablanca (1,170 miles). Tri-weekly.

(2) Malaga-Tangier-Rabat-Casablanca (250 miles). Five-weekly.

(3) Paris-Bordeaux-Madrid-Lisbon (1,000 miles). To pen next spring.

Fleet: Salmson (260 hp.) airplanes are used on routes 1 and 2 ; Farman Goliath (two $260 \mathrm{hp}$. Salmson) airplanes are to be used on route 3 .

Compagnie Franco-Bilbaine de Transports Aéronaus tiques. Bordeaux.
Route: Bordeaux-Bayonne-Bilbao-Santander-Gijon (330 miles). Tri-weekly. Only the section BayonneBilbao is in operation.

Fleet: Lévy (300 hp. Renault) and Tellier (200 hp. Hispano) flying boats.

Compagnie Aérienne Francaise. Paris.

Route: Nimes-Nice (130 miles). Bi-weekly.

Fleet: A.R. (190 hp. Renault) airplanes.

"L'Aéronavale," Société Maritime de Transports Aériens. Marseille.

Route: Marseille-Port Mahon-Algiers (470 miles). To open next spring.

Fleet: Lioré cabin flying boats.

Compagnie Transaérienne de l'Est. Strasbourg.

Routes to be opened next spring:

(1) Strasbourg-Brussels-Antwerp (250 miles)

(2) Strasbourg-Frankfort a.M. (120 miles)

(3) Strasbourg-Zurich (90 miles).

(3) "King Albert Air Line": Kinshasa-Stanleyville, Belgian Congo (1,125 miles). Three trips to be made monthly.

Fleet: Bréguet, DH 9, DH-4 and Salmson 2-passenger airplanes are operated on routes 1 and 2 ; Lévy (300 hp. Renault) flying boats are used on route 3 .

Routes 1 and 2 will have daily service by next spring.

Holland

Koninglijke Luchtvaart Maatschappij (K.L.M. Line) Amsterdam.

Routes: (1) Amsterdam-London (259 miles). Daily. (2) Amsterdam-Bremen (170 miles) Daily.

Fleet: Fokker F.II 5-passenger airplanes (185 hp. B.M.W.).

Germany

Deutsche Luftreederei. Berlin. Routes :

(1) Berlin-Leipzig-Nurem berg-Munich ( 330 miles)

(2) Berlin-Swinemünde (110 miles ).

(3) Berlin-Leipzig-Frankfort a.M. (270 miles)

(4) Danzig-Memel-Riga (320 miles). To open next summer.

Fleet: A.E.G., Albatros and Rumpler airplanes.

Lloyd Luftverkehr Sablatnig. Berlin.

Routes:

(1) B e r li n-Bremen (195 miles)

(2) Bremen-Hamburg-Co(2) Bremen-Hamb
penhagen (240 miles)

\section{Great Britain}

Air Post of Banks, Lt. London.

Routes: London-Paris (223 miles). Bi-weekly.

Fleet: Westland 5-passenger airplanes (300 hp. Hispano-Suiza).

This route is to be extended next spring to Bordeaux, Madrid and Lisbon in conjunction with the Latecoere Line of Paris.

Air Transport and Travel, Ltd. (Airco Line). London.

Routes: London-Paris (223 miles). Two trips daily.

Fleet: Airco-18 8-passenger airplanes (450 hp. Napier) ; Airco-16 4-passenger airplanes (360 hp. RollsRoyce); Airco-9 2-passenger airplanes (360 hp. Rolls. Royce).

Handley-Page Transport, Ltd. London.

Routes: (1) London-Paris (223 miles). Daily. (2) London-Brussels (210 miles). Daily.
(3) Bremen-Hamburg-Warnemünde-Malmoe (200 miles).

(4) Bremen-Gelsenkirchen-Frankfort-Munich (450 miles).

(5) Bremen-Amsterdam (170 miles).

Fleet: Sablatnig (260 hp. Mercedes) cabin airplanes.

Denmark

Danske Luftfahrtselskab. Copenhagen.

Routes: (1) Copenhagen-Hamburg-Bremen

$(240$ miles).

(2) Copenhagen-Malmoe-Warnemunde (120 miles). These services have been suspended until the opening of spring.

Norsk Luftfartrederi. Kristiania.

(1) Stavanger-HaugesundBergen (120 miles). Daily.

(2) Kristiania-Kristiansand 200 miles).

Fleet: Supermarine flying boats for route 1 , Dornier (260 hp. Mercedes) flying boats for route 2 .

Service on these routes has been suspended until next spring.

Portugal and Colonies

Macao Aerial Transport Company. Macao.

Routes:

(1) Macao-Hongkong-Canton (150 miles)

(2) Hongkong-S w a t o wAmoy-F o och ow - Shanghai $(1,100$ miles $)$. Projected.

(3) London-Amsterdam (259 miles). Daily; tem orarily suspended.

Fleet: Handley-Page W. 8 14-passenger and Handley-Page 0-410 10-passenger airplanes for routes 1 and 2; Airco-9 and Airco-4 2-passenger airplanes for route 3 .

Instone Air Line. London.

Routes: London-Paris (223 miles). Irregular.

Fleet: Vickers-Vimy 12-passenger and Airco-9 2passenger airplanes.

\section{Belgium}

Syndicat National pour l'Etude des Transports Aériens. ("Sneta -Line"). Brussels.

Routes: (1) Brussels-Paris (155 miles), Tri-weekly.

(2) Brussels-London (210 miles). Tri-weekly.

\section{Colombia} lin.

Routes: Baranquilla-Medellin (400 miles). Irregular.

Fleet: Farman Goliath 14-passenger airplanes (two 260 hp. Salmson)

The foregoing catalogue of air services is, of course, subject to change from day to day. Indeed, since it has been compiled there may be several additions and some changes, since air transport is more or less a dayto-day affair and must remain so for some time to come. undertaken. It is a basis for future compilations. 